\title{
Feksofenadyna - przegląd literatury w kontekście skuteczności i bezpieczeństwa
}

\section{Fexofenadine - a literature review focused on efficacy and safety}

dr hab. n. med. Adam J. Sybilski, prof. CMKP

1 II Klinika Pediatrii, Centrum Medyczne Kształcenia Podyplomowego w Warszawie Kierownik Kliniki: dr hab. n. med. Adam J. Sybilski, prof. CMKP

${ }^{2}$ Klinika Chorób Dziecięcych i Noworodkowych, Centralny Szpital Kliniczny Ministerstwa Spraw Wewnętrznych

i Administracji w Warszawie

Kierownik Kliniki: dr hab. n. med. Adam J. Sybilski, prof. CMKP

\section{Streszczenie:}

Lekami pierwszego rzutu w alergicznym nieżycie nosa (sezonowym i całorocznym) oraz przewlekłych pokrzywkach są leki blokujące receptory $\mathrm{H}_{1}$ (leki przeciwhistaminowe). Jednym z lepiej poznanych i przebadanych leków przeciwhistaminowych nowej, II generacji, jest feksofenadyna. To doustny, długo działający dwubiegunowo, niesedatywny, odwrotny agonista receptora $\mathrm{H}_{1}$ (przyłącza się do tej samej części receptora co agonista, ale wywołuje odwrotny efekt), wykazujący powinowactwo do receptorów histaminowych sprzz̨żonych z białkiem G. Feksofenadynę cechuje minimalny metabolizm w wątrobie i jest wydalana głównie z kałem po aktywnym transporcie do jelita. Skuteczność kliniczna feksofenadyny: poprawa w złagodzeniu objawów alergicznego nieżytu nosa i pokrzywki była oceniana w wieloośrodkowych badaniach, które wykazały jej działanie przeciwhistaminowe, przeciwalergiczne i przeciwzapalne. Feksofenadyna znacznie bardziej hamowała wystąpienie bąbla i rumienia wywołanego histaminą w porównaniu z placebo i lekami I generacji. Liczne badania dowiodły, że feksofenadyna jest bezpiecznym lekiem niepowodującym sedacji, powikłań sercowo-naczyniowych, a jej działania niepożądane (głównie biegunka) są łagodne i szybko ustępuja.

\begin{abstract}
:
The first-line drugs in allergic rhinitis (seasonal and perennial) and chronic urticaria are $\mathrm{H}_{1}$ receptor blockers (antihistamines). One of the better known and tested new generation antihistamines is fexofenadine. It is an oral, long-acting, bipolar, non-sedative, inverse agonist of the $H_{1}$ receptor (binds to the same part of the receptor as the agonist but produces the opposite effect), with affinity for $G$ protein-coupled histamine receptors. Fexofenadine is minimally metabolized in the liver and is excreted mainly in the stool after its active transport to the intestine. The clinical efficacy (improvement in the severity of the symptoms of allergic rhinitis and urticaria) of fexofenadine was assessed in multicenter studies that showed its antihistaminic, antiallergic and anti-inflammatory effects. Fexofenadine significantly more inhibited the occurrence of wheal and histamine-induced erythema compared to placebo and I generation drugs. Numerous studies have shown that fexofenadine is a safe drug that does not cause sedation, cardiovascular complications, and the side effects (mainly diarrhea) are mild and quickly disappear.
\end{abstract}

Słowa kluczowe: feksofenadyna, skuteczność, bezpieczeństwo, alergiczny nieżyt nosa, pokrzywka

Key words: fexofenadine, efficacy, safety, allergic rhinitis, urticaria 


\section{Wstęp}

Częstość występowania chorób alergicznych, takich jak alergiczny nieżyt nosa (ANN), astma alergiczna, przewlekła pokrzywka idiopatyczna i atopowe zapalenie skóry (AZS), stale rośnie od ostatnich kilkudziesięciu lat, dotykając dużej liczby osób na całym świecie, w tym również w Polsce $[1,2]$. Objawy wywołane chorobami alergicznymi, takie jak świąd nosa i skóry, kichanie, wyciek i blokada nosa, w znacznym stopniu obniżają jakość życia [3-5]. W leczeniu chorób alergicznych jako leki pierwszego rzutu są szeroko stosowane leki przeciwhistaminowe. Dzieje się tak, ponieważ w reakcjach alergicznych kluczową rolę odgrywa działanie histaminy, głównie poprzez receptor $\mathrm{H}_{1}$. Na skutek reakcji antygen-przeciwciało histamina uwalnia się z komórek tucznych, pobudzając te receptory. Pierwsze leki blokujące receptory $\mathrm{H}_{1}$ powstały w latach 40 . XX w. i obecnie feksofenadyna. Mechanizm jej działania, identyczny jak innych nowoczesnych leków, np. desloratadyny, bilastyny i rupatadyny, polega na konkurencyjnym i odwracalnym łączeniu się z receptorami $\mathrm{H}_{1}$, co blokuje komórki tuczne i hamuje uwalnianie i działanie histaminy jako mediatora procesu zapalnego. Jest to doustny, długo działający dwubiegunowo, niesedatywny, odwrotny agonista receptora $\mathrm{H}_{1}$ (przyłącza się do tej samej części receptora co agonista, ale wywołuje odwrotny efekt), wykazujący powinowactwo do receptorów histaminowych sprzężonych z białkiem G. Feksofenadyna stanowi jeden z najsilniejszych preparatów przeciwhistaminowych dzięki wybitnej swoistości i powinowactwie do ludzkich receptorów $\mathrm{H}_{1}$. Lek powoli dysocjuje $\mathrm{z}$ receptora $\mathrm{H}_{1} \mathrm{i}$ bezpośrednio hamuje wiele etapów alergicznej kaskady zapalnej. Podany doustnie dobrze wchłania się z przewodu pokarmowego, osiągając szczytowe stężenie we krwi po mniej więcej godzinie.

Tabela 1. Działania niepożądane leków przeciwhistaminowych I i II generacji [9].

\begin{tabular}{|c|c|c|c|}
\hline $\begin{array}{l}\text { Leki przeciw- } \\
\text { histaminowe }\end{array}$ & Wpływ na OUN & Wpływ na układ sercowo-naczyniowy & Objawy przedawkowania \\
\hline I generacja & $\begin{array}{l}\text { pobudzenie, splątanie, dystonia, dyskine- } \\
\text { zy, omamy, bóle głowy, sedacja } \\
\text { zaburzenia: koordynacji, uczenia się, } \\
\text { pamięci, funkcji psychomotorycznych } \\
\text { i czuciowo-ruchowych. }\end{array}$ & $\begin{array}{l}\text { zależny od dawki częstoskurcz zatokowy, } \\
\text { tachykardia, wydłużenie okresu refrakcji } \\
\text { przedsionków i arytmie nadkomorowe }\end{array}$ & $\begin{array}{l}\text { ciężkie działania niepożądane ze strony } \\
\text { OUN i serca - jeśli nie są leczone, mogą } \\
\text { prowadzić do śmierci }\end{array}$ \\
\hline II generacja & $\begin{array}{l}\text { minimalne skutki uboczne lub ich brak, } \\
\text { zmienne (np. sedacja po cetyryzynie) }\end{array}$ & brak wpływu & $\begin{array}{l}\text { brak doniesień o ciężkich symptomach } \\
\text { przedawkowania lub śmierci }\end{array}$ \\
\hline
\end{tabular}

OUN - ośrodkowy układ nerwowy.

dysponujemy ponad 40 substancjami o działaniu przeciwhistaminowym. Obecnie leki przeciwhistaminowe dzielimy na I i II generacji. Leki przeciwhistaminowe I generacji nie są już zalecane ze względu na ich działania niepożądane, w tym hepatotoksyczność, kardiotoksyczność, działanie uspokajające, działanie antycholinergiczne i brak selektywności w stosunku do receptora $\mathrm{H}_{1}$ (tab. 1). Ze względu na te skutki uboczne opracowano leki przeciwhistaminowe II generacji o mniejszej zdolności do przekraczania bariery krew-mózg, mniejszym wpływie na sercowe kanały jonowe i lepszej selektywności receptora, co pozwoliło na wyeliminowanie niepożądanych efektów wywoływanych przez leki przeciwhistaminowe I generacji. Obecnie II generacja leków zastąpiła I i leki te są rekomendowane jako leki pierwszego rzutu w leczeniu ANN i pokrzywki [6-12].

\section{Feksofenadyna - ogólna charakterystyka}

Jednym z lepiej poznanych i przebadanych leków przeciwhistaminowych nowej, II generacji, jest
Biodostępność leku wynosi ok. 30\%, a czas półtrwania - od 11 h do 15 h. W ok. 80\% wiąże się z białkami krwi.

Feksofenadynę cechuje minimalny metabolizm w wątrobie i jest wydalana głównie w kale po jej aktywnym transporcie do jelita [4]. Choć stężenie feksofenadyny w osoczu może być zwiększone przez te produkty, nie stwierdzono istotnych reakcji i działań niepożądanych z tym związanych. Aktualne dane wskazują, że lek może być przyjmowany razem z posiłkami, nawet zawierającymi produkty hamujące aktywny transport do jelita [13-16].

W wielu krajach feksofenadyna została zatwierdzona jako tabletka doustna i płynna zawiesina do łagodzenia symptomów ANN u dzieci $\geq 2$. r.ż. lub pokrzywki $\geq 6$. m.ż. W Polsce jest zarejestrowana od 6. r.ż. Zalecana dawka dla dzieci w wieku $\geq 12$ lat i dorosłych to $120 \mathrm{mg}$ i $180 \mathrm{mg}$ raz dziennie [17]. Doustna zawiesina feksofenadyny (30 mg, 2 razy dziennie) jest zalecana w leczeniu sezonowego ANN u dzieci w wieku 2-11 lat. Dla dzieci $>6$. r.ż. dostępna jest doustna tabletka feksofenadyny (niedostępna w Polsce). 
Skuteczność i bezpieczeństwo feksofenadyny były oceniane w wielu badaniach i podsumowane w metaanalizach $[9,13,18]$.

\section{Przegląd badań - skuteczność}

Skuteczność leków przeciwhistaminowych można przedstawiać na podstawie oceny klinicznej po ich zastosowaniu lub wpływu na bąbel i rumień histaminowy (w 24 h po ich zastosowaniu) [19-21]. Wiele randomizowanych, kontrolowanych placebo badań wykazało skuteczność feksofenadyny. Do oceny klinicznej stosowano skale nasilenia objawów ANN i pokrzywki (TSS, total symptoms score) [22-26]. Wykazano, że podawanie feksofenadyny 2 razy dziennie skutecznie zmniejszało wszystkie symptomy ANN, w tym przekrwienie błony śluzowej nosa, a zmniejszenie objawów utrzymywało się przez cały okres badania. Co ważne, chociaż leki przeciwhistaminowe są ogólnie uważane za nieskuteczne w zmniejszaniu przekrwienia błony śluzowej nosa, wykazano, że feksofenadyna znacząco łagodzi wszystkie symptomy sezonowego ANN, w tym również przekrwienie błony śluzowej nosa [9].

Analizując skuteczność feksofenadyny na podstawie jej wpływu na bąbel i rumień histaminowy, przedstawiono metaanalizę 51 badań klinicznych [13]. $\mathrm{W}$ porównaniu feksofenadyny $\mathrm{z}$ innymi lekami przeciwhistaminowymi II generacji procesy hamowania bąbla i rumienia wywołanych histaminą nie różniły się (dla bąbla: WMD - średnia ważona różnica $=-17,56$; 95\% CI od $-44,77$ do 9,65; p = 0,21, i rumienia: WMD $=4,58 ; 95 \% \mathrm{CI}$ od 40,70 do 49,85; $\mathrm{p}=0,84)$. W porównaniu z placebo wyniki wskazywały, że feksofenadyna powodowała znacznie wyższy wskaźnik hamowania bąbla i rumienia (odpowiednio WMD $=-18,93$; 95\% CI od 15,29 do 22,57; $\mathrm{p}<0,00001$ oraz $\mathrm{WMD}=35,75$; 95\% CI od 18,67 do 52,83; p < 0,00001). Podobne wyniki potwierdziło badanie porównujące wpływ różnych leków przeciwhistaminowych. Stwierdzono, że feksofenadyna zaczyna działać wcześniej niż lewocetyryzyna i desloratadyna, choć po zastosowaniu desloratadyny obserwowano dłuższe zahamowanie wielkości bąbelków [21].

\section{Przegląd badań - bezpieczeństwo}

Bezpieczeństwo leków przeciwhistaminowych ocenia się na podstawie ich wpływu na ośrodkowy układ nerwowy (OUN) i układ sercowo-naczyniowy oraz analizy skutków ubocznych. Bezpieczeństwo feksofenadyny było szeroko badane $\mathrm{u}$ dorosłych i dzieci w wieku szkolnym, a niektóre badania kliniczne oce- niały bezpieczeństwo feksofenadyny u dzieci przed 6. r.ż. Przy ocenie działania różnych rekomendowanych dawek doustnych nie zaobserwowano tendencji w zakresie działań niepożądanych. Feksofenadyna ma podobny profil bezpieczeństwa jak placebo [9, 13]. Przegląd systematyczny i metaanaliza wykazały, że nie było istotnej różnicy w częstości występowania poważnych działań niepożądanych między feksofenadyną a placebo u pacjentów z okresowym ANN [18]. Feksofenadyna cechowała się dobrą tolerancją i dobrym profilem bezpieczeństwa. Objawy uboczne były łagodne i samoustępujące.

Najczęściej zgłaszanym działaniem niepożądanym przez chorych na ANN leczonych feksofenadyną podczas badan klinicznych był ból głowy, ale występował z częstością podobną do placebo [9]. Ponadto długoterminowe badania na zdrowych ochotnikach w wieku 12-65 lat wykazały, że feksofenadyna jest bezpieczna i dobrze tolerowana, gdy dawki do $240 \mathrm{mg}$ są podawane raz dziennie przez okres do 12 miesięcy [27].

Wpływ feksofenadyny na sen mierzono za pomocą elektroencefalografii i polisomnografii, odpowiednio analizując zmiany biochemiczne w mózgu oraz nocny sen. Test wielokrotnej latencji snu został również wykorzystany do oceny senności w ciągu dnia. Badania te potwierdziły brak wpływu feksofenadyny na sedację [28, 29]. Odróżnia to pozytywnie II generację od I, która wydłużała czas do zaśnięcia i fazę z szybkimi ruchami gałek ocznych (REM, rapid eye movement) oraz skracała czas trwania snu REM. Nie odnotowano takich latencji snu w przypadku feksofenadyny i innych doustnych leków przeciwhistaminowych II generacji [9].

W metaanalizie wpływu feksofenadyny na funkcje poznawcze na podstawie oceny zdolności przetwarzania informacji, szybkości reakcji, stopnia skupienia uwagi, czujności i zmęczenia oraz stopnia senności stwierdzono, że obecnie dostępne dowody wskazują na minimalne, porównywane z placebo, działanie uspokajające i zaburzenia funkcji poznawczych/psychomotorycznych przez ten lek. Pod tym względem feksofenadyna przewyższa inne doustne leki przeciwhistaminowe II generacji [30]. Niedawny przegląd systematyczny sugerował, że feksofenadyna została zaklasyfikowana jako lek przeciwhistaminowy o najmniejszym upośledzeniu psychoruchowym w porównaniu ze wszystkimi innymi lekami przeciwhistaminowymi na rynku japońskim [31].

Z uwagi na potencjalnie niekorzystny wpływ leków przeciwhistaminowych II generacji na układ sercowo-naczyniowy, dość dobrze przebadano efekt feksofenadyny na zapis elektrokardiografii (EKG, electrocardiogram) u dorosłych. Nie zaobserwowano istotnego 
wpływu na częstość akcji serca, na wydłużenie odstępu PR (czas od początku załamka P do początku zespołu QRS), zespołu QRS, odstępu QT lub QTc (skorygowany odstęp QT). U zdrowych dorosłych ochotników pojedyncze dawki do $800 \mathrm{mg}$ i dawki wielokrotne do 690 mg 2 razy dziennie wykazały profil bezpieczeństwa kardiologicznego podobny do placebo $[32,33]$. Ponadto w wielu badaniach wykazano, że feksofenadyna nie ma zależnego od dawki wpływu na odstęp QTc, a bezpieczeństwo sercowo-naczyniowe jest pełne do dobowej dawki 1380 mg [32, 33]. Jednocześnie badania te pokazały, że u osób leczonych feksofenadyną nie występują działania niepożądane związane $\mathrm{z}$ hepatotoksycznością.

Bezpieczeństwo feksofenadyny zostało potwierdzone również u kobiet $\mathrm{w}$ ciąży. Ostatnio opublikowano doniesienie badaczy z Danii na podstawie obserwacji obecności wad wrodzonych i samoistnych poronień u prawie 8 tys. kobiet w ciąży przyjmujących feksofenadynę. Stosowanie feksofenadyny w porównaniu z przyjmowaniem cetyryzyny podczas ciąży nie wiązało się ze zwiększonym ryzykiem poważnych wad wrodzonych (częstość występowania OR = 1,06; $95 \%$ CI $0,81-1,37)$ lub poronienia samoistnego $(\mathrm{HR}=$ 0,93; 95\% CI 0,82-1,07). Podobne wyniki otrzymano, analizując przedwczesne porody (częstość występowania OR $=0,97 ; 95 \%$ CI 0,83-1,12), zahamowanie wzrostu płodu (częstość występowania OR = 0,98; 95\% CI $0,87-1,12$ ) oraz urodzenie martwego dziecka (HR $=0,67 ; 95 \%$ CI 0,36-1,27) [34]. Tak więc stosowanie feksofenadyny w ciąży nie wiąże się ze zwiększonym ryzykiem niekorzystnych skutków dla płodu.

\section{Podsumowanie}

Feksofenadyna ma silne działanie przeciwhistaminowe, które jest podobne do innych doustnych leków przeciwhistaminowych II generacji. Feksofenadyna ma korzystny profil bezpieczeństwa, lepszy niż leki przeciwhistaminowe I generacji. Niektóre obecnie dostępne dane wskazują, że ma ona mniejsze działanie uspokajające i sedacyjne oraz mniejszy wpływ na funkcje poznawcze i psychomotoryczne.

\section{Piśmiennictwo}

1. Samolińnki B, Raciborski F, Lipiec A et al. Epidemiologia Chorób Alergicznych w Polsce (ECAP). Alergol Pol. - Polish JAlergol. 2014; 1: 10-8.

2. Raciborski F, Kłak A, Czarnecka-Operacz M et al. Epidemiology of urticaria in Poland - nationally representative survey results. Adv Dermatol Allergol. 2018; XXXV(1): 67-73.
3. Linneberg A, Dam Petersen K, Hahn-Pedersen J et al. Burden of allergic respiratory disease: a systematic review. Clin Mol Allergy. 2016; 14: 12.

4. Meltzer EO. Allergic Rhinitis: Burden of Illness, Quality of Life, Comorbidities, and Control. Immunol Allergy Clin North Am. 2016; 36: 235-48.

5. Romano M, James $S$, Farrington $E$ et al. The impact of perennial allergic rhinitis with/without allergic asthma on sleep, work and activity level. Allergy Asthma Clin Immunol. 2019; 15: 81 .

6. Bousquet J, Schünemann HJ, Togias A et al. Next-generation Allergic Rhinitis and Its Impact on Asthma (ARIA) guidelines for allergic rhinitis based on Grading of Recommendations Assessment, Development and Evaluation (GRADE) and real-world evidence. Allergic Rhinitis and Its Impact on Asthma Working Group. J Allergy Clin Immunol. 2020; 145(1): 70$-80 . e 3$.

7. Scadding GK, Hellings $P W$, Bachert $C$ et al. Allergic respiratory disease care in the COVID-19 era: A EUFOREA statement. World Allergy Organ J. 2020; 13(5): 100124.

8. Scadding GK, Smith PK, Blaiss $M$ et al. Allergic Rhinitis in Childhood and the New EUFOREA Algorithm. Front Allergy. 2021; 2: 706589 .

9. Meltzer EO, Rosario NA, Van Bever $H$ et al. Fexofenadine: review of safety, efficacy and unmet needs in children with allergic rhinitis. Allergy Asthma Clin Immunol. 2021; 17: 113.

10. Samolinski B, Krzych-Falta E, Piekarska B et al. ARIA 2019 - zintegrowana opieka w alergicznym nieżycie nosa-Polska. Alergol Pol. - Polish J Alergol. 2019; 6(4): 111-26.

11. Dressler $C$, Rosumeck $S$, Werner RN et al. Executive summary of the methods report for 'The EAACI/GA 2 LEN/EDF/WAO Guideline for the Definition, Classification, Diagnosis and Management of Urticaria. The 2017 Revision and Update'. Allergy. 2018; 73(5): 1145-6.

12. Zuberbier T, Aberer W, Asero $R$ et al. Wytyczne eAAcI/GA2Len/eDF/WAO dotyczace definicji, klasyfikacji, diagnostyki i leczenia pokrzywki. Alergol Pol. - Polish J Alergol. 2020; 7(1): 1-28.

13. Huang $C Z$, Jiang ZH, Wang J et al. Antihistamine effects and safety of fexofenadine: a systematic review and Meta-analysis of randomized controlled trials. BMC Pharmacol Toxicol. 2019; 20(1): 72 .

14. Sybilski AJ. Feksofenadyna skuteczny i bezpieczny lek w alergicznym nieżycie nosa oraz pokrzywce. Medycyna Faktów. 2017; 4(3): 35-6.

15. Sybilski AJ. Feksofenadyna - fakty mówia same za siebie. Medycyna Faktów. 2019; 3(44): 238-41.

16. Akamine Y, Miura M. An update on the clinical pharmacokinetics of fexofenadine enantiomers. Expert Opin Drug Metab Toxicol. 2018; 14(4): 429-34.

17. ChPL, Allertec Fexo, $120 \mathrm{mg}$. https://polpharma.pl/wp-content/uploads/2021/01/221949_.pdf(access: 12.11.2021). 
18. Compalati E, Baena-Cagnani R, Penagos $M$ et al. Systematic review on the efficacy of fexofenadine in seasonal allergic rhinitis: a meta-analysis of randomized, double-blind, placebo controlled clinical trials. Int Arch Allergy Immunol. 2011; 156(1): 1-15.

19. Church MK, Maurer M. H1-antihistamines and urticaria: how can we predict the best drug for our patient? Clin Exp Allergy. 2012; 42(10): 1423-9.

20. Schoepke N, Church MK, Maurer M. The Inhibition by Levocetirizine and Fexofenadine of the Histamine induced Wheal and Flare Response in Healthy Caucasian and Japanese Volunteers. Acta Derm Venereol. 2013; 93: 286-93.

21. KC S, Aryal A, Adhikary $M$ et al. Comparative Efficacy of Fexofenadine Versus Levocetrizine Versus Desloratadine via 1\% Histamine Wheal Suppression Test. Kathmandu Univ Med J. 2020; 69(1): 19-22.

22. Iriarte Sotés P, Armisén M, Usero-Bárcena T et al. Efficacy and Safety of Up-dosing Antihistamines in Chronic Spontaneous Urticaria: A Systematic Review of the Literature. J Investig Allergol Clin Immunol. 2021; 31(4): 282-91.

23. Ring J, Hein R, Gauger A et al. Desloratadine Study Group. Once-daily desloratadine improves the signs and symptoms of chronic idiopathic urticaria: a randomized, double-blind, placebo-controlled study. Int J Dermatol. 2001; 40(1): 72-6.

24. Compalati E, Baena-Cagnani R, Penagos M. et al. Systematic review on the efficacy of fexofenadine in seasonal allergic rhinitis: a meta-analysis of randomized, double-blind, placebo-controlled clinical trials. Int Arch Allergy Immunol. 2011; 156(1): 1-15.
25. Hampel FC, Kittner B, van Bavel JH. Safety and tolerability of fexofenadine hydrochloride, 15 and $30 \mathrm{mg}$, twice daily in children aged 6 months to 2 years with allergic rhinitis. Ann Allergy Asthma Immunol. 2007; 99(6): 549-54.

26. Meeves SG, Appajosyula S. Efficacy and safety profile of fexofenadine $\mathrm{HCl}$ : a unique therapeutic option in H1-receptor antagonist treatment. J Allergy Clin Immunol. 2003; 112(4 suppl): S69-77.

27. Nathan RA, Mason J, Bernstein DI et al. Long-term tolerability of fexofenadine in healthy volunteers. Clin Drug Investig. 1999; 18(4): 317-28.

28. Church MK, Church DS. Pharmacology of antihistamines. Indian J Dermatol. 2013; 58(3): 219-24.

29. Hu Y, Sieck DE, Hsu WH. Why are second-generation H1-antihistamines minimally sedating? Eur J Pharmacol. 2015; 765: 100-6.

30. Riedel WJ, Mehta MA, Unema PJ. Human cognition assessment in drug research. Curr Pharm Des. 2006; 12(20): 2525-9.

31. Isomura T, Kono T, Hindmarch I et al. Central nervous system effects of the second-generation antihistamines marketed in Japan - review of inter-drug differences using the proportional impairment ratio (PIR). PLoS One. 2014; 9(12): e114336.

32. Pratt C, Brown AM, Rampe D et al. Cardiovascular safety of fexofenadine HCl. Clin Exp Allergy. 1999; 29(suppl 3): 212-6.

33. Graft DF, Bernstein DI, Goldsobel A et al. Safety of fexofenadine in children treated for seasonal allergic rhinitis. Ann Allergy Asthma Immunol. 2001; 87(1): 22-6.

34. Andersson NW, Torp-Pedersen Ch, Andersen JT. Association Between Fexofenadine Use During Pregnancy and Fetal Outcomes. JAMA Pediatr. 2020; 174(8): e201316. 


\section{Komentarz do przeglądu literatury}

Feksofenadyna to nowoczesny lek przeciwhistaminowy II generacji. Jest to doustny, działający długo i dwubiegunowo, odwrotny agonista receptora $\mathrm{H}_{1}$. W wielu krajach feksofenadyna została zatwierdzona jako tabletka doustna i płynna zawiesina do łagodzenia objawów ANN u dzieci $\geq 2$. r.ż. lub pokrzywki $\geq 6$. m.ż. W Polsce jest zarejestrowana od 6. r.ż. lub 12. r.ż. [1]. Feksofenadyna jest jednym $\mathrm{z}$ najsilniejszych preparatów przeciwhistaminowych dzięki wybitnej swoistości i powinowactwie do ludzkich receptorów $H_{1}$. Lek powoli dysocjuje $\mathrm{z}$ receptora $\mathrm{H}_{1}$ i bezpośrednio hamuje wiele etapów alergicznej kaskady zapalnej [2].

Analizując przedstawione metaanalizy i przeglądy badań na temat skuteczności i bezpieczeństwa feksofenadyny należy stwierdzić, że jest ona jednym z lepiej poznanych i przebadanych leków przeciwhistaminowych nowej, II generacji. Istnieją różne metody porównywania skuteczności klinicznej leków przeciwhistaminowych. Najlepszą z nich jest porównanie skuteczności klinicznej poprzez podanie tych leków w przewlekłej pokrzywce spontanicznej lub ANN i monitorowanie wyniku klinicznego. Niestety oceny kliniczne mogą być niezwykle kosztowne, czasochłonne i powodować problemy etyczne i logistyczne. Jednak model bąbli i rumienia wywołanego wstrzyknięciem histaminy wydaje się najlepszym wskaźnikiem oceny skuteczności klinicznej leków przeciwhistaminowych w terapii chorób alergicznych [3-5]. Działanie przeciwhistaminowe oceniamy na podstawie stopnia zahamowania bąbla i zaczerwienienia wywołanego histaminą [6]. Efekt ten w przypadku feksofenadyny był znacząco wyższy niż w przypadku placebo i nie różnił się znacząco w porównaniu z innymi lekami II generacji. Dodatkowo, badania kliniczne wyraźnie wykazują na skuteczność w redukcji wszystkich objawów ANN, w tym blokady nosa oraz pokrzywki i świądu. Feksofenadyna wykazuje szersze działanie niż inne leki przeciwhistaminowe, zmniejszając przekrwienie błony śluzowej nosa [1]. Skuteczność tego leku potwierdzono zarówno u dorosłych, jak i u dzieci, i to już od 2. r.ż.

Działania niepożądane (AE, adverse event) leków są ściśle związane z terapią. Należą do nich: ból głowy, senność, zmęczenie, suchość w ustach, kaszel, nudności, bóle brzucha, biegunka, wysypka, krwawienie z nosa itp. Prezentowane dane jasno wskazują, że najczęstsze działanie niepożądane feksofenadyny stanowił ból głowy, który zazwyczaj był łagodny i szybko ustępujący. Ogólnie rzecz biorąc, feksofenadyna jest dobrze tolerowana, a przerwanie leczenia z powodu działań niepożądanych zwykle występuje $\mathrm{u}<5 \%$ pacjentów [7]. Wszystkie leki przeciwhistaminowe I generacji i większość leków przeciwhistaminowych II generacji powodują kardiotoksyczność poprzez hamowanie muskarynowego cholinoreceptora (M-ChR). Badania wykazały, że feksofenadyna nie wydłużała odstępu QT i nie powodowała arytmii, gdy była stosowana samodzielnie lub w połączeniu z innymi lekami, takimi jak ketokonazol i erytromycyna. Nie stwierdzono również hepatotoksyczności. To wszystko dowodzi, że feksofenadyna ma lepszy profil bezpieczeństwa w porównaniu z innymi lekami przeciwhistaminowymi II generacji [8].

Efekt uspokajający (sedacja) jest jednym z najbardziej niepokojących działań niepożądanych leków przeciwhistaminowych. Obecne badania wskazują, że ryzyko sedatywnego działania feksofenadyny jest mniejsze niż w przypadku leków przeciwhistaminowych I i II generacji i jest podobne do placebo. Dzieje się tak, ponieważ feksofenadyna nie przechodzi przez barierę krew-mózg [9]. Biorąc to pod uwagę, eksperci w Stanach Zjednoczonych zalecili Narodowej Agencji Aeronautyki i Przestrzeni Kosmicznej (NASA) upoważnienie pilotów do stosowania w razie potrzeby właśnie feksofenadyny [10]. Należy również podkreślić, że przyjmowanie feksofenadyny w ciąży nie wiąże się ze zwiększonym ryzykiem niekorzystnych skutków dla płodu.

Podsumowując, feksofenadyna, lek przeciwhistaminowy II generacji, nie tylko nie wykazuje działania sedatywnego i skutków ubocznych na układ sercowo-naczyniowy, lecz także została oceniona jako lepsza od innych leków przeciwhistaminowych pod względem terapii objawów ANN i pokrzywki [11-13]. Dodatkowo feksofenadyna wiąże się z większą satysfakcją z leczenia u dzieci i dorosłych pod względem skuteczności, tolerancji, wpływu na sen, zaburzania funkcji poznawczych oraz wyników w szkole $[1,8,14]$.

\section{Piśmiennictwo}

1. Meltzer EO, Rosario NA, Van Bever $H$ et al. Fexofenadine: review of safety, efficacy and unmet needs in children with allergic rhinitis. Allergy Asthma Clin Immunol. 2021; 17: 113.

2. Sybilski AJ. Feksofenadyna - skuteczny i bezpieczny lek $w$ alergicznym nieżycie nosa oraz pokrzywce. Medycyna Faktów. 2017; 4(3): 35-6.

3. Church MK, Maurer M. H1-antihistamines and urticaria: how can we predict the best drug for our patient? Clin Exp Allergy. 2012; 42(10): 1423-9.

4. Schoepke N, Church MK, Maurer M. The Inhibition by Levocetirizine and Fexofenadine of the Histamine induced Wheal and Flare Response in Healthy Caucasian and Japanese Volunteers. Acta Derm Venereol. 2013; 93: 286-93.

5. KC S, Aryal A, Adhikary $M$ et al. Comparative Efficacy of Fexofenadine Versus Levocetrizine Versus Desloratadine via 
1\% Histamine Wheal Suppression Test. Kathmandu Univ Med J. 2020; 69(1): 19-22.

6. Monroe EW, Daly AF, Shalhoub RF. Appraisal of the validity of histamineinduced wheal and flare to predict the clinical efficacy of antihistamines. J Allergy Clin Immunol. 1997; 99(2): S798-806.

7. Smith SM, Gums JG. Fexofenadine: biochemical, pharmacokinetic and pharmacodynamic properties and its unique role in allergic disorders. Expert Opin Drug Metab Toxicol. 2009; 5(7): 813-22.

8. Huang CZ, Jiang ZH, Wang J et al. Antihistamine effects and safety of fexofenadine: a systematic review and Meta-analysis of randomized controlled trials. BMC Pharmacol Toxicol. 2019; 20(1): 72.

9. Hiraoka K, Tashiro M, Grobosch T et al. Brain histamine HI receptor occupancy measured by PET after oral administration of levocetirizine, a non-sedating antihistamine. Expert Opin Drug Saf. 2015; 14(2): 199-206.

10. Du Buske L. Pharmacokinetics/pharmacodynamics and psychomotor performance aspects of antihistamine therapies. Clin Appl Immunol Rev. 2001; 1: 277-89.

11. Compalati E, Baena-Cagnani R, Penagos M et al. Systematic review on the efficacy of fexofenadine in seasonal allergic rhinitis: a meta-analysis of randomized, double-blind, placebo-controlled clinical trials. Int Arch Allergy Immunol. 2011; 156(1): 1-15.

12. Meeves SG, Appajosyula S. Efficacy and safety profile of fexofenadine $\mathrm{HCl}$ : a unique therapeutic option in H1-receptor antagonist treatment. J Allergy Clin Immunol. 2003; 112(4 suppl): S69-77.
13. Jauregui I, Mullol J, Davila I et al. Allergic rhinitis and school performance. J Investig Allergol Clin Immunol. 2009; 19(suppl 1): 32-9.

14. Ferrer M, Morais-Almeida M, Guizova M et al. Evaluation of treatment satisfaction in children with allergic disease treated with an antihistamine: an international, non-interventional, retrospective study. Clin Drug Investig. 2010; 30(1): 15-34.

ORCID

A.J. Sybilski - ID - http://orcid.org/0000-0003-2389-277X

Konflikt interesów/Conflict of interests:

Nie występuje.

Finansowanie/Financial support:

Nie występuje.

Etyka/Ethics:

Treści przedstawione w artykule są zgodne z zasadami Deklaracji Helsińskiej, dyrektywami

EU oraz ujednoliconymi wymaganiami dla czasopism biomedycznych.

Copyright: (C) Medical Education sp. Z 0.0. This is an Open Access article distributed under the terms of the Attribution-NonCommercial 4.0 International (CC BY-NC 4.0). License (https:// creativecommons.org/licenses/by-nc/4.0/), allowing third parties to copy and redistribute the material in any medium or format and to remix, transform, and build upon the material, provided the original work is properly cited and states its license.

Adres do korespondencji

dr hab. n. med. Adam J. Sybilski, prof. CMKP II Klinika Pediatrii, Centrum Medyczne Kształcenia Podyplomowego w Warszawie

Klinika Chorób Dziecięcych i Noworodkowych, Centralny Szpital Kliniczny Ministerstwa Spraw Wewnętrznych i Administracji w Warszawie 02-507 Warszawa, ul. Wołoska 137 